\title{
African Americans in Urban Catholic Schools: Faith, Leadership and Persistence in Pursuit of Educational Opportunity
}

\author{
Paul Green
}

Published online: 7 October 2010

(C) The Author(s) 2010. This article is published with open access at Springerlink.com

\begin{abstract}
A review of research on US Catholic education reveals that race is not treated as an important area of analysis like class and gender. Black Catholics are rarely studied in education let alone mainstream writings. This article examines the social and educational history of blacks in the US Catholic Church and the dual reality of inclusion and exclusion within a Church and its schools. This paper focuses on the intersection of the Church and Black Catholic schools as enduring institutions of opportunity for Black families and their communities. This paper unearths the shared values, assumptions and beliefs about African American Catholics quest for literacy. The article uses Black Theology as a frame to explain how the intersections of culture, history and religion influence meaning and educational decision-making. African Americans pursued Catholic education for two reasons. First, they sought to be educated which both advanced their individual freedom but vastly improved their community's economic, social, and political standing. Second, they inserted their own unique cultural and social experiences into Catholic schools which espoused service and academic excellence. Black Catholic schools well-defined values and academic excellence is still viewed by African Americans as places of hope and opportunity for students of color.
\end{abstract}

Keywords Catholic schools · Urban education · Educational opportunity

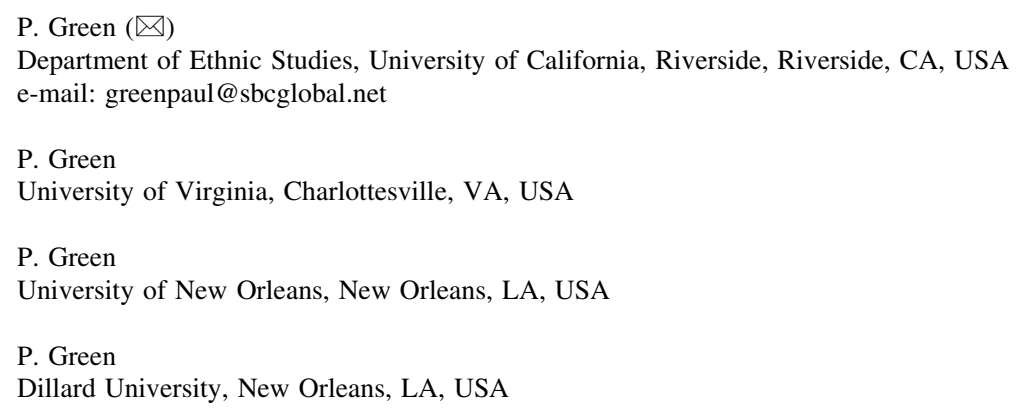


A review of research in US Catholic education reveals that unlike class and gender race is not treated as an important area of analysis. Black Catholics are rarely studied in education let alone mainstream writings. The historical and social underpinnings of African Americans and the US Catholic Church community have primed the landscape and revealed a two-fold reality. This article examines the social and educational history of blacks in the US Catholic Church and the dual reality of inclusion and exclusion within the Church and its schools.

Although Black Catholic schools have been considered "alternatives of excellence" Franklin, 1988, to Black parents and children in the inner city for more than 100 years, there is a less than positive side. This paper unearths the shared values, assumptions and beliefs about African American Catholics quest for literacy. The article uses Black Theology as a frame to explain how the intersections of culture, history and religion influence meaning and educational decision-making.

African Americans pursued Catholic education for two reasons. First, they sought to be educated which vastly improved their individual freedom and their community's economic, social and cultural standing. Second, they inserted their unique cultural and social experiences into Catholic schools which espoused service and academic excellence.

This duality that Black Catholic's have experienced is well situated in social history which connects current events with past situations. The result is a more complete snapshot of the influences of the African American experience upon the US Catholic Church and Catholic education. Black Catholic schools primarily located in older inner-city neighborhoods instilled well-defined values and academic excellence is still viewed by African Americans as places of hope and opportunity for students of color.

Contemporary scholarship indicates that both during and each decade after the Civil War, opportunities for African American education emerged because this group persistently sought to become literate. Education was both a means for individual and professional improvement and an absolute necessity in challenging their subjugation in society and the church. Education was also a way to form social and cultural relationships and maintain more cohesive communities.

A sense of community has shaped the Black Catholic experience. This group used their social and cultural capital to mobilize around their experiences of enslavement, freedom, collective desire for learning and limited resources to establish a system of Catholic education. Social capital is defined as social organizations, cultural institutions, voluntary civic associations, family groups in a community that assist in developing economically. Cultural capital refers to the sense of group consciousness that is used as a resource in the development of collective economic and social enterprises (Spann in Franklin 2004).

Social and cultural capital and the strength of human spirit were predominately all that was available to African Americans who sought inclusion in economic, political, religious and educational opportunities all of which were either limited or denied them in segregated American churches, schools and society. An intense desire to be included in the larger society manifested itself in joining religious groups like the Catholic Church and becoming educated through Catholic schools. 
Here African Americans could glimpse and feel what it might be like to experience equal footing in society.

Black Theology, a religious study, slowly emerged during the US civil rights protests in poor inner-city neighborhoods. This spiritual movement sees Christianity in terms of a liberation from unjust political, economic, or social conditions. It has been described as an interpretation of Christian faith through the poor's suffering, their struggle and hope, and a critique of society and the Catholic faith and Christianity through the eyes of the poor (Cook 1995; Copeland 1998).

This spiritual development helps to make Christianity part of their social experiences and thus more relevant and rich for African-Americans. It explains Christianity as a matter of liberation here and now, rather than in an afterlife. Black Theology contends that dominant cultural and social norms have dishonored Christianity, and the result is a mainstream faith-based empire that serves its own interests, not the community. Black Theology asks whose side should the Church be on-the side of the oppressed or the side of the oppressors. If the Church values justice over victimization, then Black theology asserts that all oppressed people be liberated. This article will explore Black Theology within the Catholic Church and its role in moving African American Catholic's and the education of African American students from poor inner city neighborhoods toward educational opportunity and leadership within their communities and society.

African American Catholics who make up nearly 4\% of the US Catholic population, continue to seek equal opportunity in the Church and in Catholic schools. Although the population of African American Catholics is relatively small, African Americans of Catholic and Christian faith dominate the enrollments of older inner city Catholics schools. The distinctiveness surrounding this group's social and historical quest for literacy and experiences in the US make it an important yet unexamined area of study.

\section{Christian Religion and the African American Slave Experience}

African American religion was essential to community building and social cohesion brought about by the social and cultural disintegration caused by slavery. Stuckey (1987) argues in Slave Culture "Christianity provided a protective exterior beneath which more complex less familiar religious principles and practices were operative" (p. 35). When singing Spirituals, dancing in worship, and baptizing, African slaves in the Americas engaged in a Christianity imbued with "deeper African religious concerns" (Stuckey quoted in Young 2006, p. 390).

Stuckey questioned whether enslaved Africans' contentedness could be located in the ubiquity of slave songs and dance. He challenged the idea that slaves sang simply because they were happy. He referred to Frederick Douglas who maintained that slaves sang not because they were happy, but rather sang, "when they were most unhappy"; that singing soothed the pains of slavery "only as an aching heart is relieved by its tear" (Douglass quoted in Stuckey 1987, p. 19). He further asserted that when slaves sang of freedom, they not only meant freedom from sin, but that the arts of African slaves revealed a deep resistance to slavery. Stuckey believed 
that the arts, especially Negro spirituals, offered bondsmen and women an opportunity to relate "to divinities on terms more West African than American" (p. 6). In this way, enslaved Africans not only used their artistic traditions to oppose slavery, but did so on their own terms by referring to West African ritual practices, divinities, and cosmologies.

African slaves from West and Central Africa came to the Americas with many different tongues, practices, customs and manners. Eventually, these diverse enslaved people, formed a singular determination to create continuity. African slaves searched for common forms of communication and social contact. The Ring Shout was one of those forms.

The Ring Shout was the main context in which Africans recognized values common to them. Wherever in Africa the counterclockwise dance was performedit is called the Ring Shout in North America; the dancing and singing being directed to the ancestors and to the gods (Stuckey 1987). Importantly, Stuckey argues that the Ring Shout is "key to understanding the means by which [African slaves] achieved oneness in America (1987, p. 14)". Those who participated in the Ring Shout remembered Africa. This memory was based in materiality that is, based on aesthetic expression. "Stuckey's Ring Shout held in its ritualized dance the memory of life before slavery and its oppressions" (Young 2006, p. 396). In short, "the cultural ethos among enslaved Africans...is rooted in the expression of cultural meanings held in common. The Ring Shout was an activity that...was...irrevocably linked in the minds of the enslaved to the horrors of slavery [and] the slave trade and a particular West African cultural zone where dances and rituals around the ring were commonplace" (p. 396).

Slave masters helped eliminate the African slave's identity and maintain the social disintegration of slavery by eradicating their collective memory. BhanaYoung (2006) argues in Haunting Capital, memory is not just a single individual's recollection of sights, sounds and smells. Memory are a collection of shared feelings, values and experiences that exist with and without us, a knot of material forces/spirits whose trace lingers long before and after us. Young suggests that, "their traces [memory] affect the material world". Memory also operates on the level of practice as described in Stuckey's Ring Shout as a ritual that consists of "a social landscape where resistant bodies, through time as dense as fog imperfectly re-member, limb by limb, that which has been imperfectly forgotten" (Bhana-Young quoted in Young 2006, p. 6). One example of memory is found in the gestural and behavioral rememory in various African cultures throughout the Americas. Thompson and Cornet (1981) note that linguists have documented a virtual dictionary of words, phrases and gestures used by African Americans whose roots suggest West and West Central African origins.

Slaves were expected to suppress their Western African heritage, language, and traditions and conform to European social, legal and religious norms in the Americas. Some plantation owners forbade both dance and drum on southern plantations and communities. Some cities allowed slaves to gather weekly and on Sunday (Kmen 1972; Johnson 1991; Cook 1995).

During the 18th and 19th centuries, slaves often met separately during weekly and Sunday services from their slave masters in keeping with the social and legal 
norms of segregation. French and Spanish slave owners permitted slaves to gather and set up market, to sing, dance and play music. In St. Augustine, Florida, or New Orleans, Louisiana, slaves met in the Place Congo or Congo Square. Here observers witnessed African-style dancing, music, languages and religion that had survived slavery. Sunday gatherings reinforced African traditions in the cities Churches, schools and public markets (Kmen 1972; Johnson 1991).

Slaveholders believed Christianity had a disciplining influence on the slave's subordination believing it to promote consent by slaves to the legal and moral authority of slavery. However, the use of religion as an instrument of social control was not strictly enforced. Most slaves took advantage of this religious freedom to create a counter-identity and assert some control over their condition of enslavement. Confronted by the practices of social control that suppressed them, a black cultural identity evolved in the Americas among enslaved Africans through Christianity. In the freedom of religious worship, using song, folklore and dance, enslaved Africans and African Americans established a community and culture that spoke to the diversity of their origins even as it instigated the development of a new identity (Cook 1995).

To the surprise of many slaveholders and Christian leaders, slaves called upon collective rememory to transform Christian scripture intended to subordinate them into a catalyst for the reconstruction of their own identity and community destroyed by slavery. This deconstruction was both revolutionary and pragmatic. The slaves' appropriation of Christianity through the lens of re-memory served as a bulwark against the degradation of slavery. It proved that alternative interpretations of Biblical text justified their humanity, identity and spirituality.

Slaves and freedmen preached that scripture had an alternative interpretation that called for the eradication of slavery. African gospel preachers, slaves and freedmen learned to read the written word against their masters' wishes and state law. They were determined to become literate and interpret Christianity through their lived experiences as slaves and freedmen in the Americas. As a community, they realized that scriptural messages of absolute obedience to slavery and social subordination were a distortion of the Bible's truths. Even when slavery seemed most unbearable, understanding their oppression as the sin of the unfaithful allowed them a sense of dignity, hope and identity.

Embracing Christianity for African Americans provided the basis for surviving the indignities and hardships of emancipation, reconstruction and decades of segregation. Christianity continued to serve as a fortifying factor for African American communities and churches faced with social and legal practices of subordination and exclusion. Each decade, the children of former slaves migrated from the fields in the South to factories and neighborhoods in the North, Midwest, and West. Here they sought improved educational, economic and social opportunities. As they resettled, they brought their collective memories of language, dance and song.

African American Churches, both Protestant and Catholic, resonated with the rhythmic cadence of "call and response" In African cultures, call-and-response is a pervasive pattern of democratic participation in public gatherings, in the discussion of civic affairs, in religious rituals, as well as in vocal and instrumental musical expression. This African tradition has been transmitted over the years in various 
forms of expression in religious observance; public gatherings; even in children's rhymes; and, most notably, in music in its multiple forms: gospel, blues, rhythm and blues, jazz and jazz extensios, hip-hop and go-go (Foster 2001). The sounds of praying, shouting or singing Negro spirituals like "Go Down Moses" punctuated the message of the preacher or priest reminding the congregation of the evils of slavery and their deliverance from it.

By the 1950s, African American Churches remained vital social, cultural and educational institutions in African American cities and neighborhoods (Hill 2007). They continued to serve their historic role of reaffirming the rich identities of African Americans. The civil rights protests of the 1960s forced African American Church leaders and their communities to rethink the identity of what it meant to be African American and Christian. The result was the formation of Black Theology.

\section{African American Catholic Identity in Black Theology}

Black Theology is a relatively new phenomenon birthed within the past 50 years. Yet, its origins are as ancient as the rich religious culture of Africa and its roots that are found in the pre- and post-Civil war experiences of slaves. It found expression in negro spirituals, sermons, blues and stories of oppressed people (Braxton 2003). These stories and songs expressed dreams of freedom. The Black approach to theology is rooted in the positive identification and creation of African American culture, history and faith rooted in the church McGann and Lumas 2001).

Black Theology has a two-fold task. First, it tells the black story of Christian faith in the US. Secondly, it gives a Christian interpretation of the American black experience behind this faith. It is a concept that outlines the heritage and faith of African and African American people enduring more than 200 years of legal and customary segregation, discrimination and subordination in the US (Cepress 1993; Davis 1990; Hayes and Davis 1998; Southern 1996). Copeland (1998) carefully states, Black Theology distinguishes Sacred Scripture as the word of God from Sacred Scripture as a European-based ideology that benefits white Protestants and white Catholic members. It directly links to the struggle of black people for freedom and liberation to the message of the gospel (p. 123).

While Black Theology focuses on historical and social liberation, it did not lessen the importance of the Christian claim for holiness of life and spiritual health. Rather, it emphasized a connection between the freedom of people and the social freedom that makes spiritual and self actualization fully possible. Black Theology embodies a universal concern that extends to oppressed persons while advocating for the liberation of all groups and persons as well as the oppressor (Copeland 1998). The moral integrity of African American Catholicism and the theology that directs it demands an unequivocal rejection of segregation. Still, racism by white clergy and hierarchy often results in separate Catholic schools for African Americans (and American Indians and Hispanics, Asian Americans) in the development of a responsive spiritual and educational praxis (Copeland 1998).

Because racism remains an unfortunate reality in the US and the world, Black Catholic Theology must wrestle with a postmodern analysis of race. Critical race 
theory confronts the historical centrality and complicity of law in upholding white supremacy. As it applies in this case, critical race theory, interrogates the policies and practices of institutional racism that denied evangelization and education of African American communities and its children (Bell 1992; Delgado 1990; Crenshaw et al. 1995; Higginbotham 1978; West 1995; Williams 1991). This theory contests both spurious and positive theories of race and racial identity. Using postmodern strategies, African American culture critics' Bell Hooks and Victor Anderson, among others, expose the delimiting treatment of racial identity as essentialist (Anderson 1995; Hooks 1990, 1994). Anderson (1995) argues for an intellectual retreat beyond ontological blackness, that is, "understanding black life as bound by truncated, unresolved binary dialects of slavery and freedom, Negro and citizen, insider and outsider, black and white, struggle and survival, with no possibility of transcending or mediating these fruitfully" (p. 14).

Consequently, the current daily lives of African Americans remain influenced by this duality and its persistent attacks on their cultural identities and intellectual abilities. Prominent mathematician and educational scholar Dr. William Tate (1994) reflects on this duality when he was a student at Holy Angels High School in Chicago, Illinois.

"Staying in college preparatory was difficult for me to negotiate at school. As a high school senior, my counselor and a school administrator attempted to remove several African American classmates and me from a physics course. No attempt was made to remove any White students. This physics course was being taught by a scholar-in-residence from MIT. The administrators justified their actions on the basis of our average grades in a chemistry course. My counselor argued, "This course is not for you." We were able to remain in the course on the basis of three arguments. First, our chemistry teacher never returned a single examination to us. We argued that our grades were determined by how this teacher perceived us as scientists, rather than on our achievements. Second, each of us had earned above average grades in prerequisite courses: biology, algebra, geometry, and mathematical analysis. Finally, each of us had near-perfect scores on the science portion of the ACT examination. Reluctantly, the school administrator and my counselor allowed us to return and continue the course". (p. 247)

Tate's (1994) recounting of his academic experiences underscores the humiliation of being "thin-sliced". This term, "thin-sliced" was coined by Malcolm Gladwell, author of Blink, who writes about rapid cognition or judgments that are made in the blink of an eye. Most of the time "thin slicing" works well for us as we follow our intuitions. At other times, it can mislead us or give us the wrong results. For instance, he presents examples where the mind works based on biases that do not necessarily enter the realm of conscious thought, but are nevertheless there (Gladwell 2005). In the case of African American Catholics and the story that Tate tells, the biases are evident and harmful. He adds,

"...it took years to overcome the psychological scars associated with this degradation. 
Part of the healing has included reexamining my dilemma and response at the time. Creating a physical space for ourselves in the physics course was only part of the dilemma. A larger battle should have been waged against the philosophical tenets embedded within the school's administrative framework; elitism and dysconscious ${ }^{1}$ racism" (p. 247).

In his narrative, Tate (1994) reveals the common assumptions which devalue the social, emotional, spiritual and educational growth of talented and bright African American students. These common assumptions can be even more blatant as experienced by Mary, a 7 year old African American Catholic student.

Mary says,

"I realized I was different from my classmates in second grade when I learned the entire class had been invited to a classmate's birthday party. Everyone, that is except me. I asked the birthday girl about it. She told me that she wanted to invite me but her father told her she could not. My mother explained that some people just did not like Black people and that was enough for me. I was comfortable with the knowledge that it was the girl's father, not she, who disliked me. (Dilworth 1996)

Black Catholic Theology can benefit from critical race theory when it includes the complexity of contemporary social, political, economic, cultural and educational relationships grounded in historical analysis. The theory must support the forming of African American identity in which relationships with "others" shape the self without its connections to oppressive forces (Copeland 1998). The theory must also dissolve the black-white polarity of race relations, without appropriating the untenable position that racism is dead or superficially elevating the essentialist position. More importantly, the application of Critical Race theory in Black Theology suggests the possibility for promoting cultural, social, educational, and practical dialogue and collaboration among ethnic groups of color competing for self-interests. Nowhere are these possibilities more important than in the troubled inner-cities of the US where poor communities of color struggle to educate their families (Copeland 1998).

African American Catholicism begins in colonial America, reaches past slavery, Reconstruction and decades of migration from fields to urban neighborhoods into a slow and methodical reliance on faith, the good intentions of some members in the Catholic Church and individual leadership within the African American community.

\footnotetext{
1 King (1991) cited in Tate (1994) uses the term disconsciousness to explain the behavior and attitude of many white teachers:

Dysconsciousness is an uncritical habit of the mind (including perceptions, attitudes, assumptions, and beliefs) that justifies inequality and exploitation by accepting the existing order of things as given. Dysconciousness racism is a form of racism that tacitly accepts dominant White norms and privileges. It is not an absence of consciousness (that is not unconsciousness) but an impaired consciousness or distorted way of thinking about race as compared to, for example, critical consciousness (p. 135).
} 


\section{The First African American Catholic's}

African slaves arrived with their Spanish and French missionary owners in what is now the United States during the earliest days of European colonization. Vernon C. Polite (1996) says that "records from the 1500s show that some of the earliest Africans and African-Caribbean settlers in the colonies professed Catholicism" (p. 62). Spanish explorer Lucas Vasquez de Ayllon brought African slaves to coastal South Carolina to establish a settlement in 1526. Within four more years, African slaves accompanied numerous Spanish expeditions to the New World from presentday Florida to California.

The first Catholic missionaries in North America were the Spanish who settled in the West and in the East at St Augustine, Florida, the first permanent city in North America built by non-Native Americans. In 1606, the first documented slave birth was recorded in St. Augustine. Agustin was baptized in the Catholic faith. He was the son of Agustin and Francisca, both listed as slaves in church baptismal records.

Slavery in New France, near the St Lawrence River and into present-day Canada, was first recorded in 1628 when a British fleet delivered a slave boy from Madagascar who was given the name Olivier le Jeune. His name is reflective of a tradition in New France that would give slaves a name from prominent Catholic figures.

By the early 1700s, Africans began arriving in greater numbers in New France, mainly as slaves to the French aristocracy. Slavery was further fortified by the Raudot Bill of 1709. The bill was an ordinance that recognized slavery in New France as law. African slaves arrived with the French who populated Quebec and areas that spread from the Hudson Bay to port cities like New Orleans, Louisiana Charleston, South Carolina, and New London, CT in the 1600s and 1700s.

African slaves and Catholic missionaries lived with a mixture of Christian ideals and the harsh realities of an economy that would eventually be built upon slave labor. In the New World, Missionary Catholic priests, nuns and brothers attempted to adhere to a decree passed by France's King Louis XIV in 1685 called the Black Code (Code Noir). The decree mandated that slaves be baptized in the Catholic Church and educated in the ways of Catholicism.

The sacramental registers of New Orleans record the baptism and marriage of nearly 200 African slaves between 1763 and 1803. Ursula nuns owned these slaves and were primarily responsible for recording their official baptisms and marriages in the US. These documents provide important details about family formation and community stability like the slave's name, their children and the daily work that they performed.

\section{The First African American Catholic Schools}

The liberal treatment of free and enslaved African Americans in Catholic French settlements supported Ursula nuns in starting one of the first Catholic schools in North America. The Ursula Academy opened in 1727 to educate free African American girls in New Orleans, Louisiana (Davis 1990; McDermot and Hunt 1991). 
In 1728 , the nuns enrolled seven enslaved girls into their boarding school located in their convent.

Many of the earliest schools for African American Catholics were opened in slaveholding states that were Catholic strongholds like Maryland and Louisiana. The Oblate Sisters of Providence, an African American religious order, opened the second Catholic school called St. Francis Academy for Colored Girls in Baltimore, Maryland in 1828 (Geredes 1988). The Sisters of St. Joseph opened a school for free African American girls in 1845 in Carbondale, Missouri. The school was soon forced to close due to racial bigotry and the resulting community pressures aimed at keeping African Americans uneducated.

The opening of more schools in cities soon followed. The Oblate Sisters eventually opened more schools in Baltimore for free African American children including the St. Francis Boys School in 1852 and St. Michael's and St. Joseph's Schools in 1857 (Davis 1990; Franklin 1996; Yeager et al. 1985). St. Augustine's School opened in Washington, DC to provide for the children of freed slaves (Davis 1990).

Between 1890 and 1917, Catholic religious orders opened 76 schools for African American children in the US (Polite 1992). Although the call to baptize and educate slaves was well known by Catholic religious orders who settled in the US, it was selectively followed and rarely enforced by slave owners in the US (Davis 1990; Frazier 1971; Foley 1969; Gillard 1929; Higginbotham 1978). Instead the Church often followed state slave codes or widely-held local customs which denied religious and academic education to African American families and their children.

The Catholic Church in North America failed to baptize or provide religious instruction to every African American especially during the colonial period for two reasons. First, Catholic missionaries led by religious orders (e.g. Jesuits, Capuchins, Sulpicians, Ursuline nuns) often owned African slaves. Slaves accompanied missionary nuns, brothers and priests to unsettled territories (Gillard 1929; Davis 1990). Slave labor in the tobacco fields of Maryland and the cotton fields of the South and the West supported the financial survival of these missionaries. Contrary to Black Code recommendations, slaves worked every day even on Catholic holy days. Because Catholic missionaries profited from slave labor, some were often less than ambivalent about the religious conversion or schooling of their slaves (Davis 1990; Curran 1983; Gillard 1929; Davis and Phelps 2003).

State slave codes provided another reason to deny religious instruction. These codes prohibited slave owners from teaching slaves to read or write (Higginbotham 1978). The Catholic population of the colonial South and the ante-bellum south was mostly white and black and few in number. As slave communities expanded, slave owners both Catholics and Protestants, feared the possibility of slave revolts and insurrections brought about through literacy by way of religious instruction. Cyprian Davis (1990) in the History of Black Catholics in the US poignantly notes, in the antebellum era Catholic Bishops reminded Catholic slave owners of their duty to furnish their slaves with opportunities for being [well] instructed, and for practicing their religion, yet genuine efforts to provide religious instruction and schooling for enslaved Africans remained nonexistent (p. 44). So, while some Catholic missionaries regularly baptized slaves, little historical evidence suggests religious 
schooling for slaves was an overall mission of the Roman Catholic Church. Some local and higher church leaders continued to follow the prevailing social attitude that most freed and enslaved African Americans were inferior human beings who were best suited for labor and did not need or deserve the practical benefits that might come from education.

\section{The Beginnings of Leadership and Change}

Since slavery largely destroyed the social basis of religion among African Americans, denominations that stressed order like Catholicism attracted only some African Americans both free and enslaved. Many African American slaves, especially in the South, were socialized primarily to Protestant religions like Episcopalian, Methodist, and Baptist like their predominantly Protestant slave owners. The faith of the slave owner was often the faith of the slave. African American Catholic's were the product of a melding of attachments to European and American owners.

By the 1850s, African American Catholic's were clearly a presence in a few US cities including New Orleans, Louisiana; Mobile, Alabama; Savannah, Georgia; St. Louis, Missouri; Washington, D.C.: and Baltimore, Maryland.

Parishes in these cities comprised the largest communities of free African American Catholics (Davis 1990; Davis and Phelps 2003). They operated free schools for both white and free African American children to learn reading, writing and catechism. In the parishes of Washington, DC and Baltimore, Maryland, free African American Catholics received religious education denied to the same group in segregated southern Catholic churches during the antebellum period (Gillard 1929; Davis and Phelps 2003).

According to Franklin and McDonald (1988), "in both Northern and Southern cities separate Black Catholic schools were created by Roman Catholic diocesan and religious orders acting with diocesan approval and by transformation of previously predominately White parish schools to all-Black schools" (p. 100). In the southern and border states, where segregation was law and social policy, diocesan policy mirrored these laws and customs requiring segregation in churches, public accommodations and public education (Franklin and McDonald 1988; Ilg et al. 2004; Sowell 1976). African American Catholics were treated as objects of charity in most Catholic churches and schools rather than Christian sisters and brothers with a common faith and a common origin (Davis 1990; Franklin 1996).

White lay people expressed little knowledge or value for the history and culture of persons of indigenous or African descent in the US (Davis 1990; Davis and Phelps 2003; Southern 1996). African American lay Catholics voiced their discontent with both segregation and racial discrimination in the Catholic Church and society. Moreover, they protested the lack of religious instruction and schools. The prejudice that slavery sealed into the psyche of Americans remained a powerful influence upon the ability of African Americans to receive religious instruction and share the same experience as their Euro-Catholic counterparts in the Church. 
The Church simply insisted that slavery was more a political matter than a moral one (Davis 1990; Davis and Phelps 2003).

By 1843, free lay Catholics in the African American community in Baltimore, Maryland formed the Society of the Holy Family. The society of 270 members selfgoverned their religious, social and political activities and met every Sunday in Calvert Hall in the cathedral parish. Sunday meetings consisted of written and spontaneous prayers coupled with the singing of religious hymns and on occasion Negro spirituals. The spontaneity of prayer and song through traditional hymns and spirituals was sometimes magnified by the cultural rhythms of call and response which survived as a part of African heritage (Brown 1998; Davis 1990; Hayes and Davis 1998).

The society established financial independence from the local parish. Every member paid dues which were used to rent Calvert Hall, purchase chairs, benches, lamps, book shelves and to support the schooling of free African American girls at St. Francis Academy in Baltimore. In addition, dues were used to promote religious instruction and literacy. The society established a lending library in Calvert Hall which included catechisms, devotional literature, lives of the saints, and Catholic hymnals. Each member could borrow a book for one cent per month and for one cent each consecutive week. Lending libraries were extremely rare and important in this period when few formal opportunities for education for poor persons or African Americans existed. When the Catholic Church denied the society access to Calvert Hall in 1845, the worship services were disbanded and its lending library dismantled (Gillard 1929; Davis 1990).

After the Civil War ended, Roman Catholic Bishops noticed that many groups in the South needed basic literacy through religious instruction. Literacy laws and poorly-funded public schools in the war-torn South ensured poor whites, free African Americans and slaves received little or no education. Catholic missionaries, religious and philanthropic associations in the North and teachers entered the South in the hopes of converting these groups to Catholicism. These efforts offered some religious schooling for free African Americans. Yet, the rapid movement of European Catholic immigrants into industrialized areas of the US shifted the Church's focus away from benefits to freed African Americans towards the maintenance of arriving immigrants (Franklin 1981). Church efforts were often scattered and short-lived (Franklin 1981, 1996).

\section{Colored Leadership and the Crusade for Social Justice and Equality}

The Church's confusion concerning the religious and educational needs of African American Catholics did not go unchallenged. Harriet Thompson, a literate African American woman from New York, wrote Pope Pius IX in 1853 to describe the damaging effects of racial segregation and the lack of schooling for African American children. She professed the devout loyalty of African American Catholics and chided the racist policies and practices of segregation and discrimination within the Catholic Church. She wrote that it was a great mistake to have the church say 
that it took equal care over every race and color when it was still not accepted that the Black race mix with the White (Davis cited in Hayes and Davis 1998, p. 37).

She received no response from the Pope.

In 1866, the Second Plenary Council of Baltimore was a group of Bishops who met once again to discuss the spiritual care and education of African Americans. The Church's hazy stand was revealed more than ever in the published council decrees. Bishops agreed on pastoral care but were divided on separate churches for the worship of African Americans in normally segregated parish churches. In brief, the council decided that Bishops with African American Catholics in their diocese should work with their white lay Catholic leaders to make local decisions. Religious instruction for African Americans in most Catholic dioceses however, did not improve as this decision to relegate the work to local parishes amounted to making no decision.

\section{African American Catholic's Persevere through Colored Congresses}

Lay leadership took matters into their own hands. The First Colored Catholic Congress was organized by Mr. Daniel Rudd, a newspaperman, in Washington, D.C. in 1889. The proceedings published by Daniel Rudd shed light on the purpose and distinction of Catholic Schools for African American children:

The education of a people being the great and fundamental means of elevating it to the higher planes which all Christian civilization tend, "we pledge ourselves to aid in establishing...Catholic Schools... "(cited in Polite 1992, p. 211). They deemed Catholic schools as essential to the maintenance of an enduring faith among African American Catholics (Franklin 1996). Rudd also addressed the critical need for schools to develop training in labor skills and family virtues (Davis 1990).

The Second Colored Catholic Congress, held in Cincinnati, Ohio in 1890, was not as euphoric as the first. And, yet, it was more pragmatic in addressing issues such as the fact that the Church provided few opportunities for black students to attend Catholic schools and colleges. At the close of the second congress, congress members agreed on a set of resolutions. The resolutions called for the creation of night schools so all Catholics could have access to religious education, for cities to enact laws to guarantee equal access by all citizens to schools, neighborhoods, parks, and swimming pools; for access by African Americans to unions and union benefits and for store keepers to hire African Americans as clerks. Shortly after, the executive committee of the Colored Catholic lay Congress met to plan the third Catholic Congress (Davis 1990).

The Third Colored Catholic Congress opened in Philadelphia, Pennsylvania in 1892 with fifty delegates. Two matters dominated the Congress' discussions: the question of education and the establishment of a permanent Colored Catholic congress. The Third congress called for racial integration in the education of black children in the Catholic schools. It also called for a permanent organization for the ongoing implementation of the designs set forth in past and subsequent congresses (Davis 1990). 
The Fourth Colored Catholic Congress took place in Chicago, Illinois in 1893. In association with the Columbian Exposition, it was the pinnacle of the Black Catholic Congress movement. The Congress demanded from the Church civil and social equality in education, public facilities and other opportunities for every citizen of the US. The most important document however, of the Fourth Congress was the final address to all Catholics, which stated that "one important feature of the address is the balance between expressions of loyalty to the church and rejection of racism within the church" (Davis 1990).

Colored Catholic Congress leaders used the grievances of the four congresses, to advocate for the individual and human rights of all men. In an era, when little was written about social justice, African American Catholics made social justice the center piece of their Catholic eccesiology and religious instruction. At the same time, they believed the Church must support the equality of all its Catholic sisters and brothers and denounce any discrimination and prejudice as counter to Catholic doctrine and morality (Davis 1990).

Equally important, in each of the congresses, lay leaders proclaimed pride in their African Catholic history and the charitable works provided by the Church to African American Catholics and non-Catholics. Historical references to Africa and the Catholic Church were common in the congress speeches. They complimented the church in saying "we rejoice that our Church, the Church of our love, the Church of our faith has not failed to stand by its historical record. For did not Holy Church canonize Augustine, and Monica, Benedict the Moor and Cyprian, Cyril, Perpetua and Felecity" (Davis 1990, p. 188). African American historian P. Sterling Stuckey (2006) in "Through the Prism of Folklore," makes clear the important relationship of Africa in shaping the religious and spiritual lives of African American freed men and slaves.

Sister Thea Bowman, a Franciscan Sister of Perpetual Adoration, eloquently affirms Stuckey's point when she asserts,

"to the Americas our people brought the secret [of] memory of Africa, the celebration of life values in an African way and style: in song and instrumentation, in story and drum, in verse and anecdote, the memory of the survival mechanisms of Africa the memory of color and texture, of culinary arts that translated even when we ate chitlins and other folks' leftovers. African people here became African American" (Bowman cited in Cepress 1993, p. 100)

Davis (1990) further asserts, "In one way or another, Africa became part of the self-understanding of American blacks throughout the nineteenth century." (p. 1)

While immigrant groups looked toward Europe for their Catholic roots, African American Catholics embraced the early Catholic Church in Africa for its cultural history and religious identity (Brown 1998; Davis 1990; Hayes and Davis 1998; Stuckey 2006) So, African American lay Catholic leaders looked to African Catholics like St. Augustine, St. Monica, St. Cyprian, and St. Cyril of Alexandria as role models (Brown 1998; Davis 1990). During the Fourth Congress, African American lay leadership reclaimed their discarded and uniquely African Catholic 
identity rooted in Christian antiquity not available to European Catholics (Brown 1998; Davis 1990).

Unlike the previous four congresses, the Fifth Colored Catholic Congress held in 1894 in Baltimore, Maryland produced no meaningful action. Apparently, Church leadership in Rome became wary of more militant lay Catholic leaders demanding Catholic schools for black students. This congress would be the last until 1987 (Davis 1990; Hayes and Davis 1998).

The Colored Catholic congresses established the words to voice the moral foundation for civil rights. Further, they galvanized a progressive and active lay leadership that forged the political and intellectual space for the establishment of the Committee for the Advancement of Colored Catholics in 1916 and later the Federated Colored Catholics in 1924 (Davis 1990).

The Federated Colored Catholics called for increased access and participation on church governing boards, to all Catholic educational institutions, and as applicants to Catholic University in Washington, D.C. These boards made decisions about recruitment, church and school funding, academic programs and retention of students.

\section{Establishing Catholic Higher Education for African Americans}

Advocacy resulted in the founding of Xavier Academy in 1914 in New Orleans, Louisiana. Xavier Academy, founded by the Sisters of the Blessed Sacrament, was opened as a secondary school to serve African American Catholic children. Franklin (1996) states that, "one reason why Xavier Academy, the Black Catholic secondary school opened in New Orleans in 1914 through the financial support of Blessed Katherine Drexel, became a collegiate institution in the 1930s was because the Catholic leadership refused to allow African American Catholic admission to its Catholic colleges and universities across the country". (p. 53) Franklin (1996) also reminds us.

With the creation of Xavier University, there was less pressure on Catholic colleges and university administrators to allow African Americans to enroll in allwhite Catholic institutions. The desegregation of Catholic higher education in the US would not take place until after World War II (p. 53).

Students of all races and nationalities attended Xavier University while they were denied admission to white Catholic Universities like Notre Dame, and Georgetown University (Davis 1990; Buetow 1971; Ilg et al. 2004).

Archbishop Joseph Ritter and Archbishop Patrick O'Boyle in 1948 desegregated Catholic Schools in both St. Louis, Missouri and Washington, D.C. This was 6 years before the Supreme Court's decision in Brown v. Board of Education (1954) that desegregated all US public schools. In these cities, white and African American priests and nuns worked with African American lay Catholics to increase social services such as night school, credit unions and Catholic fraternal organizations in their parishes. Their work contributed to unprecedented growth in the African American Catholic community in the US. 
Not until 1958, however, did US Catholic Bishops denounce racial discrimination in the US and in the Catholic Church and its schools. Still, African American Catholic clergy and lay persons continued to face racial discrimination.

Antoine Garibaldi is an African American who was educated in the Catholic Church and in its school system. He was a Catholic seminarian in high school and college. He eventually left the seminary due to the racism he encountered. He tells us a personal story about his experience as an African American boy attending Catholic school.

"I walked about eight blocks to St Joan of Arc every day with my older and younger brothers and sisters. We passed as many as five all-white Catholic schools on our way. Some even came as far away as five miles on our parish school buses. We could only attend St. Joan of Arc because it was the only allBlack Catholic Church, where all were supposed to be recognized as children of the same God, but I found it hard to understand and believe this given the religious principles and doctrines we were learning. Even more I wondered if older Black Catholics had been able to maintain their faith despite this obvious system of inequality." Garabaldi in Irvine and Foster 1996, p. 129-129)

Unfortunately, not even a Catholic identity could protect African Americans from societal discrimination or the existence of racial animus within the Catholic Church.

In another story about living Black and Catholic, Mary Dilbert describes herself in 1965 as a 9-year old African American girl who is listening to a priest present at a missionary meeting at her Catholic Church and school. Mary says that priest was showing slides and speaking about the poor pagans in a certain African country.

"At the close of the meeting, a white lady asked if I was from an African country. How absurd, I thought: even if I did physically look to her like one of the pagans, how could I be at St Mary's Church all the way from Africa without my parents? I came to the conclusion that white people did not know much about Black people or about me." (Dilworth in Irvine and Foster, pg 110)

Mary Dilbert's experience in the Catholic Church has long been commonplace among African American Catholics.

African American Catholics persisted in calling the Church's attention to the pervasive problems of widespread racism within the church, lack of access to religious instruction or admission to Catholic University and governing boards of Catholic organizations, and societal violence against Blacks. More importantly, the legacy of the congresses and the Federated Catholics of Color endowed African American Catholics with a spirit of ownership and responsibility for the Church and its schools.

\section{The Civil Rights Movement and the March to Social Justice in the Catholic Church}

Although the Church played no central role in the movement for civil rights, individuals within the Church mounted grassroots efforts. The first organized protest 
of African American priests occurred in Detroit, Michigan in 1968, following the assassination of Martin Luther King Jr. and the eruption of violence in inner-city African American communities across the country. In the same year, African American priests meeting separately from white priests assembled for the Catholic Clergy Conference on the Interracial Apostolate and organized themselves into a caucus, the first of its kind in American church history. The separate meeting of African American religious and lay Catholics addressed institutional racism and discrimination (Hayes and Davis 1998).

At its conclusion, the National Black Catholic Clergy Caucus (NBCCC), the National Black Sisters Congress (NBSC), the Black Catholic Lay Congress (BCLC) and the National Black Catholic Seminarian Association (BBCSA) presented a list of grievances to the American Catholic Bishops. Like the congresses and the Federated Catholics of Color, Black religious and lay organizations continued their grievances against racism in the church and lack of access to religious education. One of the recommendations was the formation of a National Office of Black Catholics (NOBC). In 1971, the NOBC was established in Washington, D.C. with the help of the Catholic Church. Now called the National Black Catholic Congress (NBCC), it serves as the ecclesiastical and policy clearing house for the four major African American caucuses and their conferences (Davis and Rowe 1988).

Within the NBCC, a supportive environment exists where American priests, sisters and lay persons challenged by racism could discover and celebrate their authentic African American identity. Moreover, the NBCC provides information about the rich contributions of African American Catholic evangelization and education (Hayes and Davis 1998). With the force of NBCC behind it, in 1979 the African American Bishops published a pastoral letter called Brothers and Sisters to Us, in which racism was criticized as an evil in the Church that defiled the image of God and degraded the sacred dignity of human kind (African American Bishops of the United States 1984).

Five years later, African American Bishops issued the first pastoral letter entitled, "What We Have Seen and Heard". In this pastoral letter, they reminded the Church and African American Catholics

"Within the history of every Christian community there comes the time when it reaches adulthood. This maturity brings with it the duty, the privilege and the joy to share with others the rich experience of the "Word of Life."...that the Black Catholic community in the American Church has now come of age" and that now is the time "to reclaim our roots and to shoulder the responsibilities of being both Black and Catholic". (1984, p. 17)

This proclamation to the Church established as Catholic doctrine the reclaiming of the sacred religious and cultural traditions of African Americans rooted in the African and the African American Catholic experience while also proclaiming a collective African American religious consciousness (Davis 1990; Hayes and Davis 1998).

The organized actions of African American Catholic priests, sisters and lay persons during the Civil Rights Movement signaled to the Church that there existed a more than urgent need among African American Catholics and non Catholics for a 
Black Catholic identity rooted in a positive identification of African Americans in the Church.

\section{America's Cities and the Decline of Catholic Education}

For more than 200 years, Catholic and non-Catholic African American parents have enrolled their children in Catholic schools. Catholic schools for many African American families' were educational alternatives to poorly-performing public schools (Greeley 1982; Franklin and McDonald 1988; Irvine and Foster 1996; Lyke 1991; Shields 1989; Yeager et al. 1985). However, in the 1960s, many inner city Catholic parishes and their schools experienced significant enrollment shifts as Euro-Catholic families motivated by upward mobility and racism relocated in large numbers to expanding suburbs (Franklin and McDonald 1988; Greeley et al. 1976; Greeley 1982).

Not surprising, the exodus of affluent and middle-class white families emptied many city neighborhoods where Euro-Catholics for decades financially supported and enrolled their children in Catholic schools. Non-Catholics quickly replaced them. These non-Catholics were mostly poor African Americans migrating to Northern, Mid-western and Western cities escaping the segregationist policies and the depressed economic conditions of the South (Defiore 2008; Franklin and McDonald 1988).

The rapid increase in the number of African Americans enrolled in urban Catholic schools produced a growing number of schools in those areas. The cost of financially supporting Catholic churches and rising school tuitions however was overwhelming for many African American Catholic parents. In some Catholic neighborhoods, to forestall Catholic school closures, the Catholic Church admitted non-Catholic students in larger numbers. Franklin and McDonald (1988) state that the practice touched off debate with the Church as to whether Catholic money and effort should be used for training non-Catholic children. Many Black Catholic leaders did not see this event as draining on Church resources but an opportunity for attracting Black converts.

They argued that these schools should be considered part of the Roman Catholic Church's mission to the Black community (p. 100). More importantly, Franklin and McDonald (1988) point out that the rising enrollment of African American students in urban Catholic schools was more a consequence of the deterioration of urban neighborhoods and public school systems than the conscious missionary activities of the Church.

According to Defiore (2008) these shifts were further exacerbated by a rapid nationwide decline in the school age population, namely baptismal rates of Catholic children. The school age population that boomed after Word War II soon declined to normal levels during the late 1960s and 1970s. This enrollment decline shaped by demographic forces was also intensified by the reduction in new construction of Catholic schools sorely needed in older and formerly Catholic city neighborhoods (Defiore 2008). 
Compounding the population shifts and enrollment losses was a weakening attachment to parish life as measured by declines in Church activities such as Mass attendance. Defiore (2008) states, "Not only had weekly Mass attendance declined precipitously but also record numbers of priests petitioned for dispensations from their vows and ordinations; the numbers of new vocations plummeted and the number of marriage annulments skyrocketed". A climate of questioning and challenging authority and rejecting traditional values created a growing sense of instability within the US Catholic Church. In this same period, a lack of confidence among some Catholics and the secular press further contributed to the diminished perception of the quality of academic preparation provided by Catholic schools.

The 1970s and 1980s witnessed a decline in inner-city Catholic churches and schools. The 1990s produced even more school closings. Yet, despite the closings, Catholics schools witnessed enrollment increases with the emergence of new construction primarily in smaller and mid-sized dioceses outside of urban Northern and Midwestern cities. For example, between 1985 and 1999, the Archdiocese of Washington, DC opened two elementary schools while nine more elementary schools opened in the affluent but smaller Diocese of Arlington, Virginia (Defiore 2008).

New construction of Catholic schools took place in more affluent suburbs at the same time that many older and predominantly inner-city schools remained sorely in need of repair and modernization. Still, unlike earlier periods of decline, Defiore (2008) remarked, "...nearly one-third of the schools reported waiting lists; new schools continued to be built; evidence of academic and religious effectiveness abounded and media coverage of the schools grew positively". Enrollment increases from 1990 to 2000 however were short-lived.

In fact, by 2005 the familiar pattern of enrollment declines and accelerated school closings from the 60s through the 80s primarily in large urban dioceses reappeared. The decline according to Defiore (2008) was brought on by sexual abuse scandals, escalating legal settlements, declining financial support for urban schools serving African American students, declining Catholic populations, shrinking numbers of brothers and sisters, replacement of religious order faculty with lay teachers, climbing enrollments or poor non-Catholic students, escalating teacher salaries, insurance premiums and financial instability led in a search for new sources of support.

Loss of guaranteed subsidy from state and local public school districts has meant that leaders have turned to substantial tuition increases, parish subsidies, appeals to secure government funding, private and corporate sponsorship, and the African American Catholic (AACS) governance boards. These boards serve as civic and philanthropic conduits to critical resources in the broader corporate and civic community of struggling inner-cities.

\section{Black Catholic Education: Renewing the Commitment to Evangelization}

To renew Black Catholic education in America's urban neighborhoods Catholic leaders need to consider the social and cultural history of African American 
Catholics' pursuit to educate themselves and their communities. The following questions are key to understanding the role literacy plays in renewing the social and cultural attachment of African Americans to Catholic education.

First, "what does it mean to be Black and Catholic?" As Sister Thea Bowman states:

"It means that I come to my church fully functioning. That doesn't frighten you, does it? I come to my church fully functioning. I bring myself, my black self, all that I am, all that I have and all that I hope to become. I bring my whole history, my traditions, my experience, my culture, my AfricanAmerican song and dance and gesture and movement and teaching and preaching and healing and responsibility as gifts to the church" (Bowman cited in Cepress, 1993, p. 32).

Sister Thea Bowman's quote helps explain how important bringing ones culture to ones worship can be. This move can help African Americans celebrate their strengths and break away from unhealthy assimilation.

Afrocentricity "places Africans and the interests of Africa at the center of...approach[es] to problem solving" and study (Asante 1987; Reagan 2005). Sister Thea Bowman's prophetic words to the National Council of Catholic Bishops suggest that the spiritual and educational needs of the African American child come first. She also suggests, that the ways of knowing or the cultural gifts brought by African American communities, families and students can enrich the spiritual and educational consciousness of the Catholic Church.

The second question is "What does the child need?

Chineworth asks whether depositing canonical information into children's intellect is more useful than assuming that the child, following the insight of Haki R. Madhubuti and Sister Thea Bowman, already knows and learns on the genius level. (Brown cited in Chineworth, 1996, p. 56).

To fully educate African American students, Catholic Schools must embrace the valuable culture that emanates from these students and their communities (Brown 1996, 1998; Cepress 1993; Irvine and Foster 1996; Slaughter and Johnson 1988; Waldon 1994). Sister Thea Bowman's formative experiences illustrate this important idea. Thea Bowman was placed in a Catholic school, in Canton, Mississippi, by parents who desired her to receive a "good" education.

When she started, she was not a baptized Roman Catholic (Brown in Chineworth 1996). She was cared for by African American elders, parental figures and peers; a community which demanded that she strive for educational and personal excellence. Irvine and Foster 1996 states, "no subject was considered too difficult, esoteric, or irrelevant. I was aware of the great financial sacrifices and emotional disturbances my parents experienced to keep us in Catholic school so I mastered the curriculum..." (p. 92).

Third, the African American community responsibly supported the education of its children. Like Irvine and Foster, Sister Thea Bowman, attributed her moral and spiritual development to the guidance of "old folks," reminding her audience that the triad of church, home and school was essential for her development-as well as 
for the wholistic development of all fully functioning, well-educated members of society (Bowman in Cepress 1993; Irvine and Foster 1996; Perry et al. 2003).

Finally, In Growing up African American in Catholic Schools, Irvine and Foster (1996) note that, "there existed a strong set of clearly articulated, accepted values embraced by the Catholic school educators, their students and their mostly working class or poor non-Catholic parents" (p. 172). Lisa Delpit (1995) calls this "the seamlessness between home and school" (p. 119). These important values included discipline and order, a sense of mission and purpose that is morally-based, high expectations, and an understanding of the centrality of parents and family in the education of their children and the community. Because her spiritual foundation was established and shaped by an African American church and community, and culture, she understood how indispensable and necessary these experiences remain in the redevelopment and renewal of marginalized communities, families and students.

\section{Religious and Lay Teachers in the Renewal of African American Catholic Schools}

Church, community and culture play a crucial role in the spiritual instruction and educational success of students who reside in poor, urban areas. Within these innercity neighborhoods are established Catholic schools successfully educating African American children and their communities (Polite 1992; Irvine and Foster 1996; Younis and Convey 2000).

These schools believe that prepared with the proper education, hard work, and discipline African American children can surmount societal obstacles of segregation and discrimination using the moral, social and academic opportunities provided by Catholic congregations and local churches (Irvine and Foster 1996; Polite 1992; Younis and Convey 2000). Simply put, like African American parents and their communities, some Catholic Churches and schools continue to believe that African American students can learn and achieve (Chineworth 1996; Irvine and Foster 1996; Polite 1992; Slaughter and Johnson 1988; Tate 1994). Armed with this knowledge, Bishop James P. Lyke (1987) stated that African American Catholic schools particularly in poor inner-city neighborhoods represent an opportunity for quality education and character development with the Catholic Schools remaining one of best vehicles for evangelizing within the Black community (p. 9).

An example of how these considerations have played a part in the education of African American youth is best exemplified by the work of Jesuits in several cities. In 1977, Jesuits in New York City recognized the need for middle schools or Nativity Mission Centers in poor, mostly Puerto Rican neighborhoods. In 1990, Jesuits acknowledged the same need for poor African American students in Boston, Massachusetts. Thereafter, other religious brothers and sisters educating students of color in urban inner-cities established Nativity Schools.

These schools, founded by Catholic religious orders, follow one model: select intelligent children with little previous academic success. Long academic days, long school years, parental involvement, tutoring, low cost tuition, and high school 
tuition aid are the norm. Summer school is mandatory. Religion and ethics are coupled with a nurturing academic climate of educational achievement and success.

Roughly 60 schools in cities like Washington, D.C., Durham, South Carolina, St. Louis, Missouri, and San Jose, California follow the model. Once paid for and taught by Jesuits; Nativity schools now receive less support from religious orders and require funding from private and corporate donations.

In 2005, St. Louis, Missouri was the first city to create an embedded Nativity school: St. Cecilia Academy. The idea took an existing Catholic parish school struggling with enrollment and turned its sixth, seventh and eighth grades into a Nativity school. St. Cecilia's enrollment grew from 130 to 170 students. So far, the new model is working said Tom Nolan, former director of Loyola Academy who runs a local organization created to found, finance and support new Nativity Miguel schools (Hunn 2006; McDonald 2006). In 2007, two more embedded academies opened at existing schools in the city: Holy Trinity Catholic and Central Catholic. Graduates of Nativity schools successfully enter and graduate from Catholic High schools like Cristo Rey Jesuit High School (CRJHS) in Chicago's Pilsen Little Village eventually left the seminary due to the racism he encountered in the Church.

Cristo Rey Jesuit High School (CRJHS) opened its doors in the poor Mexican Pilsen/Little Village neighborhood, the least-educated population on the Southwest side of Chicago. Cristo Rey was the newest secondary school in the Chicago diocese in 33 years. It was designed to reach the large number of poor children who did not enroll in existing Catholic schools. Each student attends classes 4 days a week and works at a clerical entry-level position in a downtown office on the fifth day.

To make this concept work, the school opened a temporary employment agency whose representatives approach Chicago business firms. When a position is negotiated, the school assigns a cohort of five students to share one full-time position and its salary each day of the week. The school also conducts follow-up work to guarantee that the team of students meets the expectations of the firm.

The salary students earn from their professional employment provides tuition for their education. CRJHS students work in more than 90 institutions, including banks, law firms, hospitals and schools. CRJHS plans to maintain itself through the Corporate Internship Program. Each full-time position costs the corporate firm $\$ 19,000$ annually. From this salary each student pays $\$ 3,800$ toward his or her tuition. All students are charged an additional $\$ 1,750$ in tuition for which they can apply for financial aid. The school receives $\$ 5,550$ per student, and with additional sponsorship from corporations and foundations like the Bill and Melinda Gates Foundation it has been successful. In fact, the growing success at CRJHS has promoted the development of four other Cristo Rey high schools enrolling inner-city students in Portland, Oregon, Austin, Texas, Los Angeles, California and Denver, Colorado.

The closure and merger of AACSs in urban inner-city neighborhoods moved the (NBCC) to designate 31 Catholic High Schools with African American enrollments exceeding 75\% as African American Catholic High Schools (AACHS). One of the goals of the NBCC is to enact national strategies and support systems that will guarantee the survival of these high schools and their service to the Catholic Church and to African American's (African American Bishops of the United States 1984). 
While 21 AACHSs were the result of shifting racial demographic patterns within these neighborhoods, 10 of the schools were established with the mission of evangelizing and educating African Americans.

Polite (in Younis and Convey 2000) named the ten historically African American Catholic Schools (HAACS) as "Cornerstone" ${ }^{2}$ schools. He asserts that success at the HAACSs is attributed to the institutional and personal support that each student receives; the caring administrators, teachers and staff, the explicit Christian values that shape a "no nonsense" approach to educational excellence. These unique schools educate "by design, and not accidentally" the academic skills essential for young, bright and talented students to consider moral and ethical problems while posing solutions. The use of Afrocentric methods in HAACSs instills a critical discursive pedagogy that embraces self-determination and improvisation for which African Americans traditionally used to defy and transcend oppression in society and the church. Copeland (1998) reflects that,

"In this African-centered worldview ambiguity is not merely tolerated but appreciated; the sacred and secular, being and doing are not separated but united; the individual person is not set apart from the community but becomes a person-incommunity. This affirms "blackness" as more than a biological fact of skin pigmentation. Blackness is color, but it is more than color; it signifies critical consciousness (p. 137).

Critical Consciousness requires the involvement of the entire community not just administrators and teachers. Elders in the African-American tradition must have significant input and ownership into the curriculum of African American Catholic Schools. Like African Griots, Elders often convey the stories of African heritage by revealing how African American religion, spirituality, language, song and dance shape the identity of its community. Elders preserve an understanding of the traditions essential to community building through social and cultural capital that sustained African Americans during and following the American slavery experience. As such, they ensure the curriculum provides the appropriate content for challenging the academic, religious, and spiritual needs of African American students. As instructional mentors, Elders provide teaching strategies connected to African and African American culture, like call and response, to clergy, lay teachers and staff.

Elder's understanding of Black Theology and spirituality helps with the active monitoring of the cultural and educational traditions that make Catholic schools "authentically African American" (Chineworth 1996; Hayes and Davis 1998; Tate 1994). Authentic teachers in African American Catholic Schools are familiar with African-American culture, and the role of Black Theology and arts in the spiritual, emotional and academic growth of their African American students and communities (Chineworth 1996; Hayes and Davis 1998; Tate 1994).

Black Catholic school presidents, principals, parents, and community volunteers are also important. Black Catholic education must have active parents and an

\footnotetext{
2 St. Francis Academy, Baltimore, Maryland, Xavier Preparatory High School and St. Augustine High School New Orleans, Louisiana, St. Jude High School, Montgomery, Alabama, Holy Family, Birmingham, Alabama, Hales Franciscan, Chicago, Illinois, St. Martin de Porres and Loyola, Detroit, Michigan, and Cardinal Ritter College Preparatory High School, St. Louis, MO
} 
involved community to produce Black Catholic scholars and leaders (Davis 1990; Hayes and Davis 1998; Irvine and Foster 1996). For African American Catholics, self-definition and self-determination is above all a human task and obligation. Copeland (1998) explains,

To name ourselves, our history, culture, intellectual, and social movements, and Catholic religious praxis "black" is an act of self-determination, defiance and courage. When we do this, we acknowledge and embrace an identity that has been shaped under duress, anxiety and rejection in our church." (p. 122)

Copeland goes onto say that Black Catholic's are not rejecting the Church's universal nature and mission but are instead giving reverence and practice to Black culture within the Church. African American culture honors those men and women of African descent whose struggles forged an abiding path of faith in the hopes of transforming society (Cattaro 2002; Irvine and Foster 1996; Tate 1994; Waldon 1994).

\section{Conclusion}

African Americans pursued Catholic religious instruction to become literate thereby trusting that they could improve their economic outlook both within and outside of their communities. They sought opportunity like all Americans to rise above their current lot in life. Catholic missionaries' early acceptance of slavery and societal norms in the US left scars and associations that made those who ran the Church unwilling to fully accept and instruct most free or enslaved African Americans. In an ironic move, some of the boldest and most pioneering members of the Catholic Church, the missionary nuns, priests and brothers in early America established the first schools for African Americans.

Once African Americans were emancipated in the mid-19th century, basic literacy included industrial and vocational training for newly freed slaves while emphasizing moral and spiritual values. Importantly, African American lay leaders believed that Catholic religious instruction eliminated illiteracy by attacking all policies and practices of racial discrimination.

African American Catholics organized groups that included five Catholic Colored Congresses and a Federation that publicly challenged racial discrimination within the Catholic Church and society. They called for more African American priests; better access to secondary Catholic education; admission for African American students to Catholic University; and more African American advisors on church policy. Until the mid-twentieth century, African American clergy and lay Catholics formed parish booster clubs, chapters, congresses, and organized conferences to transform the negative attitudes of white Catholic bishops towards "interracial justice".

By the mid-1960s, a new mood overtook African American Catholics as the "gospel of integration" was reconsidered. Rhetoric sparked by the Civil Rights movement shifted from seeking quality under the law to assuming equality by educating African American Catholics for social justice through a black theology. African American priests, sisters, nuns and lay persons gathered just as African 
American lay Catholics had done decades before. Unlike previous decades, African American clergy became a more powerful voice within the Catholic Church as the social climate came to support more equality.

Together, African American clergy and lay Catholics organized The National Office of Black Catholics, now the National Black Catholic Congress (NBCC). The NBCC evolved from antagonists toward the Church to consultants with the Church. As advisors, they issued pastoral letters including Brothers and Sisters to Us which branded racism as a sin and called for its end within the Church and society. What We Have Seen and Heard proclaimed that African American Catholics were mature Christians with the responsibility of evangelizing themselves and others. In 1987, the Bishops Committee on African American Catholics and the Secretariat for African American Catholics was established. These permanent bodies serve as catalysts from within the church's hierarchy for structural and social change on behalf of the African American Catholics and non-Catholics.

From the mid-1960s forward, "white flight" of Euro-Catholics to suburbs produced declines in urban Catholic school enrollment. These declines were exacerbated by economic recessions, political shifts in funding and changing attitudes towards social and religious authority. These shifts have translated into low Mass attendance, school closings, declines in new construction, loss of religious teachers and importantly, the loss of financial subsidies to many schools. These trends have been acute in poor and older city neighborhoods. The result has been rising enrollments of non-Catholic African American students. In fact, during the 1970 and 1980s, African American populations rapidly expanded in Northern and Midwestern inner-cities for two reasons: (1) the increase of Catholic education for African Americans and the encouragement of non-Catholic African American parents to receive instruction; and (2) the general perception that Catholicism remained a welcoming community for African Americans.

In the 1990s, most predominately African American dioceses established an office for African American Catholics at the local church level. Like previous generations, African Americans perceive the institutions of religion and education as indispensable to the well-being of their communities. In a profound expression of hope and faith, Noguera writes, they sacrifice to enroll their children "hoping against the odds that for their child, or at the particular school their child attends, something good will happen, and a better future through education will be possible" (2003, p. 5). Still, African Americans families who represent a valuable pool of talent and leadership remain concerned that their children not be alienated from their own communities due to their academic and social experiences in Catholic schools.

Most African American Catholic and non-Catholic parents acknowledge that Catholic schools represent a safe-haven for students in poorer -city neighborhoods who possess few options but to attend less than desirable public schools. Catholic schools, Polite (1992) exclaims,

...are institutions in which well-defined values and morals are taught explicitly through the curriculum and implicitly through the daily routines and co-curricular activities. An essential part of their mission is evangelization and the teaching of Christian traditions and values. Such a mission compels 
the leadership of the urban Catholic schools, where the majority of the students are African Americans to consider the history and traditions of this people when planning religious instruction and services. It is crucial that African American students be afforded the opportunity to practice the traditions of the Catholic Church without compromising their cultural heritage. (p. 220)

The grassroots and individual efforts of African American Catholic priests, sisters and lay persons during the Civil Rights Movement signaled to the Church that there existed a need among African American Catholics and non-Catholics for a Black Catholic identity rooted in a positive identification of African Americans in the Church.

Open Access This article is distributed under the terms of the Creative Commons Attribution Noncommercial License which permits any noncommercial use, distribution, and reproduction in any medium, provided the original author(s) and source are credited.

\section{References}

African American Bishops of the United States. (1984). What we have seen and heard: A pastoral letter on evangelization from the African American bishops of the United States. Cincinnatti, OH: St. Anthony Messenger Press.

Anderson, V. (1995). Beyond ontological blackness: An essay on African American religious and cultural criticism. New York, NY: Continuum Books.

Asante, M. K. (1987). The Afrocentric idea. Philadelphia, PA: Temple University Press.

Bell, D. (1992). Faces at the bottom of the well: The permanence of racism. New York, NY: Basic Books. Bhana-Young, H. (2006). Haunting capital: Memory, text, and the Black disaporic body. Hanover, NH: Dartmouth College Press.

Braxton, E. K. (2003). NBCC special report: A portrait of Black Catholics in the U.S. National Black Catholic Congress. Washington, DC: NBCC Press.

Brown, J. A. (1996). Little David, play on your harp: A philosophy of Black religious pedagogy. In M. A. Chineworth (Ed.), Rise n' shine: Catholic education and the African-American community (pp. 29-49). Washington, DC: National Catholic Educational Association.

Brown, J. A. (1998). To stand on the rock: Meditations on black catholic identity. Marynoll, New York: Orbis Books.

Brown v. Board of Education of Topeka. (1954). Kansas (BROWN I) 347 U.S. 483.

Buetow, H. A. (Autumn, 1971, Fall). The underprivileged and Roman Catholic education. Journal of Negro Education, 40(4), 373-389.

Cattaro, G. M. (2002). Catholic schools: Enduring presence in urban America. Education and Urban Society, 23(1), 100-110.

Cepress, C. (1993). Sister Thea Bowman, shooting star: Selected writing and speeches. Winona, MN: Saint Mary's Press.

Chineworth, M. A. (1996). 'Rise ' $N$ ' Shine: Catholic education and the African American community. Washington, DC: National Catholic Education Association.

Cook, A. E. (1995). Beyond critical legal studies: The reconstructive theology of Dr. Martin Luther King, Jr. In K. Crenshaw, N. Gotanda, G. Peller, \& Kendal Thomas (Eds.), Critical race theory: The key writings that formed the movement. New York, NY: New York Press.

Copeland, M. S. (1998). Method in emerging Black Catholic theology. In D. L. Hayes \& C. Davis (Eds.), Taking down our harps: Black Catholics in the United States. New York, NY: Orbis Books.

Crenshaw, K., Gotanda, N., Peller, G., \& Thomas, K. (1995). Critical race theory: The key writings that formed the movement. New York, NY: New York University Press. 
Curran, R. E. (1983). "Splendid poverty": Jesuit slaveholding in Maryland, 1805-1838. In R. M. Miller \& J. L. Wakelyn (Eds.), Catholics in the Old South: Essays in the church and culture (pp. 125-146). Macon, GA: Mercer University Press.

Davis, C. (1990). The history of black Catholics in the United States. New York, NY: Crossroad Publishing Company.

Davis, C. (1998). God of our weary years: Black Catholics in American catholic history. In D. L. Hayes \& C. Davis (Eds.), Taking down our harps: Black Catholics in the United States. New York, NY: Orbis Books.

Davis, C., \& Phelps, J. (2003). "Stamped with the image of God": African Americans as God's image in black. Maryknoll, New York: Orbis Books.

Davis, J. M., \& Rowe, C. (1988). The development of the National Office of Black Catholics, U.S. Catholic Historian, 7(2), 265-289.

Defiore, L. (2008). The financing of Catholic elementary schools: Vatican II era to the present. In P. Baugh (Ed.), Catholic schools in the public interest: Past, present and future. Charlotte, NC: Information Age Publishing.

Delgado, R. (1990). When a story is just a story: Does voice really matter. Virginia Law Review, 76(7), 95-111.

Delpit, L. D. (1995). Others people children: Cultural conflict in the classroom. New Press: New York. Foley, A. S. (1969). God's men of color. New York, NY: Arno Press.

Foster, M. (1996). Mea culpa, mea culpa, mea culpa, mea maxima culpa: The french catholic school experience. In J. J. Irvine \& M. Foster (Eds.), Growing up African American in catholic schools. New York, NY: Teachers College Press.

Foster, M. (2001). Pay leon, pay leon, pay leon: Paleontologist using call and response to facilitate language mastery and literacy acquisition among African American students. In S. Lanhart (Ed.), Socio-cultural contexts of African American English; varieties of English around the world. Amsterdam: John Benjamin Publishing Company.

Franklin, V. P. (1981). Continuity and discontinuity in Black and immigrant minority education: A historical assessment. In D. Ravitch \& R. Goodenow (Eds.), Educating an urban people: The New York City experience (pp. 44-66). New York, NY: Teachers College Press.

Franklin, V. P. (1996). First came the school: Catholic evangelization among African Americans in the United States, 1827 to the present. In J. J. Irvine \& M. Foster (Eds.), Growing up African American in Catholic schools. New York, NY: Teachers College Press.

Franklin, V. P., \& McDonald, E. B. (1988). Blacks in urban catholic schools in the United States: A historical perspective. In D. T. Slaughter \& O. J. Johnson (Eds.), Visible now: Blacks in private schools. Westport, CT: Greenwood Press.

Frazier, E. F. (1971). The Negro in the United States. New York, NY: Macmillan Press.

Gerdes, M. R. (1988, Spring-Summer). To educate and evangelize: Black Catholic schools and the oblate sisters, 1812-1880. U.S. Catholic Historian, 7(5), 183-199.

Geredes, M. R. (1988). To educate and evangelize: Black catholic schools of the oblate sisters of providence. U.S. Catholic Historian, 7(2-3), 183-199.

Gillard, J. T. (1929). Colored Catholics in the United States. Baltimore, MD: The Josephite Press.

Gladwell, M. (2005). Blink: The power of thinking without thinking. New York: Back Bay Books, Little Brown Publishing.

Greeley, A. M. (1982). Catholic high schools and minority students. New Brunswick, NJ: Transaction Books.

Greeley, A. M., McCready, W., \& McCourt, K. (1976). Catholics in a declining church. Kansas City, MO: Sheed \& Ward Publishers.

Hayes, D. L., \& Davis, C. (1998). Taking down our harps: Black Catholics in the United States. New York, NY: Orbis Books.

Higginbotham, A. L. (1978). In the matter of color, race and the American legal process: The color period. New York, NY: Oxford University Press.

Hill, K. H. (2007). Religious education in the African American tradition: A comprehensive introduction. St. Louis, MO: Chalice press.

Hooks, B. (1990). Yearning: race, gender and cultural politics. Boston, MA: South End Press.

Hooks, B. (1994). Outlaw culture: Resisting representations. New York. NY: Routlege Books.

Hunn, D. (2006, May 28). Nativity schools see first alumni go to college. P. C-1 \& C-4, St. Louis Post Dispatch, St. Louis, MO. 
Ilg, T. J., Massucci, J. D., \& Cattaro, G. M. (2004). Brown at 50: The dream is still alive in urban Catholic schools. Education and Urban Society, 36(3), 355-367.

Irvine, J. J., \& Foster, M. (1996). Growing up African American in catholic schools. New York, NY: Teachers College Press.

Johnson, J. (1991). New Orleans's Congo Square: An urban setting for early Afro-American culture formation. Louisiana History: The Journal of the Louisiana Historical Association, 32(2) (Spring, 1991), 117-157.

King, J. K. (1991). Dysconscious racism: Ideology, identity, and the miseducation of teachers. Journal of Negro Education, 15(4), 133-146.

Kmen, H. A. (1972). The roots of jazz and the dance in place congo: A re-appraisal. Anuario Interamericano de Investigacion Musical, 8, 5-16.

Lyke, J. P. (1987, February). Sharing the gifts of the black community. Momentum, 18, 8-10.

Lyke, J. P. (1991). Catholic schools: The lifeblood of evangelization. Paper presented at the special meeting of the National Congress on Catholic Schools, Washington, DC.

McDermot, M. L., \& Hunt, T. C. (1991). Catholic schools: A first in Louisiana. Momentum, 22(4), 46-50.

McDonald, D. (2006). The annual statistical report on schools, enrollment and staffing: U.S. Catholic elementary and secondary schools, 2005-2006. Washington, DC: NCEA.

McGann, M. E. \& Lumas, E. M. (2001, Spring). The emergence of African American worship. U.S. Catholic Historian, 19(2), 27-65.

Noguera, P. (2003). City schools and the American dream: Reclaiming the promise of public education. New York, NY: Teachers College Press.

Perry, T., Steele, C., \& Hillard, A. G. (2003). Young, gifted and black. Boston, MA: Beacon Press.

Polite, V. C. (1992). Getting the job well done: African American students and catholic schools. Journal of Negro Education, 61(2), 211-220.

Polite, V. C. (1996). Cornerstones: Catholic high schools that serve predominately African American student populations. In J. J. Irvine \& M. Foster (Eds.), Growing up African American in catholic schools. New York, NY: Teachers College Press.

Reagan, T. (2005). Non-western educational traditions: Indigenous approaches to educational thought and practice (3rd ed.). Mahwah, NJ: Lawrence Erlbaum Publishers.

Shields, P. H. (1989). Holy angels: Pocket of excellence. Journal of Negro Education, 58(4), $203-211$.

Slaughter, D. T., \& Johnson, D. J. (1988). Visible now: Blacks in private schools. New York, NY: Greenwood Press.

Southern, D. W. (1996). John Lafarge and the limits of catholic interracialism, 1911-1963. Baton Rouge, LA: Louisiana State University.

Sowell, T. (1976, Spring). Education and the "ghetto" school: Patterns of black excellence. The Public Interest, 43, 26-58.

Spann, C. M. (2004). 'I must learn now or not at all': Social and cultural capital in the educational initiatives of formerly enslaved African Americans in Mississippi, 1862-1869. In V. P. Franklin \& C. J. Savage (Eds.), Cultural capital and Black education: African American communities and the funding of Black schooling, 1865 to the present. Greenwich, CT: Information Age Publishing, Inc.

Stuckey, P. S. (1987). Slave culture: Nationalist theory and the foundation of black America. New York: New York University Press.

Stuckey, P. S. (2006). Afterword: Frederick Douglass and W. E. B. DuBois on the consciousness of the enslaved. The Journal of African American History, 91(4), 451-458.

Tate, W. F. (1994, October). From inner city to ivory tower: Does my voice matter in the academy? Urban Education, 29, 245-269.

Thompson, R. F., \& Cornet, J. (1981). The four moments of the sun: Kongo art in two worlds. Washington, D.C: The National Gallery of Art.

Waldon, C. R. (1994, February/March). The inner-city school: Pastoral gift or burden? Rejecting the "welfare" parish putdown a pastor speaks out for his African American community. Momentum, 20-22.

West, C. (1995). Forward. In K. Crenshaw, N. Gotanda, G. Peller, \& K. Thomas (Eds.), Critical race theory: The key writings that formed the movement (p. 11). New York, NY: The New Press.

Williams, P. J. (1991). The alchemy of race and rights: Diary of a law professor. Cambridge, MA: Harvard University Press.

Yeager, R. J., Benson, P. L., Guerra, M. J., \& Manno, B. V. (1985). The catholic high school: A national portrait. Washington, DC: National Catholic Education Association. 
Young, J. (2006). Through the prism of slave art: History, literature, memory and the work of P. Sterling Stuckey. The Journal of African American History, 91(4), 389-400.

Younis, J., \& Convey, J. J. (2000). Catholic schools at the crossroads: Survival and transformation. New York, NY: Teachers College Press. 